\title{
Economic Integration of Stock Markets: An Evidence from Pakistan, China and Malaysia Stock Exchanges
}

\author{
Tazeem Anwar ${ }^{1} \&$ M.Yousaf Raza ${ }^{2}$ \\ ${ }^{1}$ Lahore Business School, University of Lahore, Pakistan \\ ${ }^{2}$ Department of Management Sciences, Mohi Ud Din Islamic University, Islamabad, Pakistan \\ *Correspondence: Department of Management Sciences, Mohi Ud Din Islamic University, Islamabad, Pakistan. \\ E-mail: yousaf.raza@miu.edu.pk
}

Received: June 1, 2016

doi: $10.5430 / \operatorname{mos} . v 3 n 3 p 52$
Accepted: June 21, $2016 \quad$ Online Published: July 25, 2016

URL: http://dx.doi.org/10.5430/mos.v3n3p52

\begin{abstract}
The last decade Pakistani Equity Market witnessed a lot of favorable and unfavorable happenings which lead to internal markets collapse. The local investors are interested especially in the countries like China, Malaysia, UAE and Bangladesh which are politically, geographically and strategically important as investment portfolio point of view. It is experimented that if different equity markets of world are co-movement i.e. there exist long-term relationship, then the benefit of diversification by investing in different equity markets cannot be attained. Therefore, this study is important, which has explored the short/long term co-integration relationship of selected economies with Pakistani Equity Market. The main purpose and scope of this study was to explore causal and dynamic linkages of Karachi Stock Exchange, KSE-100 index (Pakistan) with emerging stock markets of Shanghai Stock Exchange, SSE (China), Kuala Lumpur Stock Exchange, KLSE (Malaysia). The study explores that the major change in KSE-100 is due to its own innovations and other markets have no significant impact on the KSE. The results show the need of future study to explore the factors of economic integration among these stock markets.
\end{abstract}

\section{Problem Statement}

The local investors are feeling themselves much insecure in indigenous investment. This study is important in which it will be explored that the selected Asian Stock Markets have any short/ long-run co-integration relationship with Pakistani stock Market or not. Thus the aim and purpose of the current research is to study the relationship and possibility of mutual investment in these stock markets.

Aim of the Study: The main aim of the current study in hand is to investigate and explore both dynamic and causal linkages ofKSE-100 index (Pakistan) of Karachi Stock Exchange, with emerging equity markets Shanghai Stock Exchange, SSE (China) and Kuala Lumpur Stock Exchange, KLSE (Malaysia).

Objectives of the study: The prime objective of the current study is to analyze short term, long term co-integration and trading pattern with the selected stock market i.e. Pakistan, Malaysia and China.

Research Question: Does Pakistani Stock Market (KSE) have any short term/long term co-integration relationship with selected Markets?

Significance of the Study: The research is having significance to see the past and identify the issue which are creating hurdles in investment and see the future possibilities to have an advantage from each other experiences for growth.

Keywords: equity/stock markets; market trends; stock prices; portfolio diversification

\section{Introduction}

The importance and significance of a stock market can be better seen in a free market economy where the companies in need of capital investment can raise the capital by issuing their company share in the stock market where by the investor buys the share on a firm mentioned share price. This trading of share not only provides a company with capital but also the investor in some part of a firm ownership. This phenomenon last for a long period of time and a company with high repute not receives a large amount of money. A better controlled, structured and fame stock market, not only 
boost financial activities but also encourages economic activities in a country. It encourages the saving and investment activities in an economy whereby not only the local ones invest in a company but the foreigner investor also takes part in the investment activities. Such investment activities turn into more productive activities and in return companies makes profit and shareholders are rewarded with the dividend. Equity market does also supports re-allocation for funds between corporations and also in the sectors. This may also provide liquidity for indigenous or domestic growth and also for credit growth. It is evident that leading equity market of the globe experienced negative (-) growth which ranged as approx. 50.7percent (Pakistan) to $2.9 \%$ (China) through the financial year 2008-09. According to (Azam and Lukman 2010)the major shareholding in Pakistan stock market is usually done by promoters, small investors and institutional investors. Their shareholding values are $40 \%, 35 \%$ and $25 \%$ respectively. Furthermore they are one whose return on their share is also tremendous. During the 1998 to 2008, Pakistan experienced 30\% equity share per annum. In parallel with other problems and volatility of the Pakistan situations, the share market also remained volatile within the last five decades. Numerous crashes were experienced by KSE but the most notable and major crashes during the last decade were the crash of KSE in 2000, 2005 and 2008. The 2008 crash of the KSE market was one of the most crashed ever observed in the country history. During this period the KSE dropped more than 10,000/- points (Economic Survey of Pakistan, 2008-2009).

During the period between, 1990-1996 tremendous growth of Malaysian Stock Market was achieved and accounted for $63.9 \%$ increase in market capitalization (Al-Fayoumi, Abuzayed et al. 2010). The value of the market capitalization and the stock during the stated period was US 306.17 billion and US178.01 billion respectively. The performance of the Malaysian stock market in 2007 remained the same as it was before the Asian financial crisis with a rise in the number of listed companied from 731 to 986 . The performance was once again affected by the global financial crisis in 2008 and a sharp decrease was recorded in 2008 as compared to growth in 2007 (World Federation of Exchanges, 2009).

Chinese stock market experienced a tremendous growth and development from the period 1990 to 2000 due to the establishment of the two exchanges in the 1990 i.e. Shanghai Stock Exchange (SSE) and Shenzhen Stock Exchange (SSE). A total number of the listed company at the end of 2001 was 1,160 started with only 10 companies in 1990. The number of listed is more than Pakistan and Malaysia. The net worth of the market capitalization was US 525.6 billion(Jones 2002).

\section{Portfolio Diversification}

After the work of (Markowitz 1952) the phenomena of portfolio selection become almost the core of all financial investments and variance optimization is still consider while the formulation of portfolio. Selection of portfolio is all about picking different securities form different markets in your investment baskets. According to him in the selection process the important consideration is co-movement between different selected stocks. It can be summarizing that the main factors of internal and external are: economic, financial, regional and policies of international and definite variables are those factors on which the speed and nature of the financial process of integration both depend on (Chancharat\&Valadkhani, 2007).

\section{Research Review}

The research analyses the previous work done in the field of stock markets, portfolio diversification. The investment on equity markets has become popular in developed countries like the US and European countries since the last many decades. Although these countries have even experienced fluctuations during stability, the investments increased especially in high tech sectors of stock markets (Gallo \& Otranto, 2007). The globalization has a positive role on the integration of the financial markets especially stock market. The growing dissemination of the information coupled with the factual deregulation and reconciliation has led to the increasing cross-border investment and capital flow (Gallo \& Otranto, 2007 and Malik, 2007). During a depression, investors switch their investment funds to more protective stocks, such as non-cyclical consumer goods sector. The most serious international recession since the Second World War led to either oil price shocks or political instability has triggered by the Middle East and North African countries (MENA) (Chang et al., 2010). The Capital Asset Pricing Model (CAPM) (1963) which was commenced by Sharp suggested that it is impossible to eliminate the systematic risk, (or 'market risk'), whereas there general argument which may be taken that investments in international equity markets not only offer the additional and ample potential profit but simultaneously reduce the total portfolio investment risk . The increase in international capital mobility is due to increase in the interaction between world economies, both developing and developed(Chen 
2005). Due to liberalization of capital markets and the development of new varieties of financial instruments, the level of international diversification of portfolios has increased.

\subsection{Portfolio Diversification}

International portfolio diversification has been considered an effective way to achieve higher risk-adjusted returns as compare to the indigenous investment alone since long. Consequently the recognition as well as magnitude of portfolio diversification benefits depends upon significantly on the relative size, frequency, persistence of idiosyncratic and common shocks(Jorion 1985).

During this century business as well as economies which are going rapidly towards more globalization has extremely enhanced the volume for investments into financial instruments. Owing to increase in the globalization, the international stock markets are rushing towards integration, like ASEAN, NAFTA, EU, MENA, and Scandinavian countries. That aspect is a positive $(+)$ signal for the global economic growth which may reduce that risk for contagion effects due to financial crisis, mainly if that which created from the larger stock markets sides.

\subsection{Global Equity Markets}

To study and check the relationship system among the Pacific-Basin region stock markets for the period 1988 to 1996 Janakiramanan and Lamba (1998) have conducted a study and found that developed market of USA is having larger effect on the Australian stock markets as compared to, but the same is not observed with other countries of the region. In the other study on the Scandinavian countries and United States of America of almost of the same period was conducted by Subrahmanyam and Mathur (1990) with the objective to find whether there is influence of US stock transaction on the countries or not. Eun and Shim (1989) studied the linkage of Australia, Canada, France, Germany, Hong Kong, Japan, UK, US and Switzerland and found the interdependence among all these traditional business partners. The variation in US markets directly affects the other countries stock markets. Kasa (1992) in his investigation found that there is a sole common trend which to the greater extent compels the equity markets of Canada, Germany, Japan, UK and USA. In addition, he suggested that there may present a long-run co-integration relationship among these equity markets. (Cheung and Ho 1991). Conducted study on eleven emerging Asian stock markets and developed markets and found that there was very little correlation among the Asian market group and the developed markets group. A study on ten Asian markets was conducted by (Divecha, Drach et al. 1992) who found that they were homogeneous with a dominating strong market force and less correlated with each other and with the developed markets. Chung and Liu (1994) studied that the 5 Asian countries and US stock markets have 4 well-known stochastic trends. Sheng and $\mathrm{Tu}$ (2010) searched long/short-term relationship between of 11 Asia-Pacific countries equity markets with the equity markets of US. The study period was comprises from July 1, 1996 to June 30, 1998. The co-movement between Malaysian stock market with other main trading partners like Japan, US and Singapore. Roca (1999) on the basis of evaluating Co-integration test examined the interrelatedness among the stock markets of Australia, Hong-Kong, Japan, Korea, U.K, U.S, Singapore and Taiwan, and found no long term relationship with Australia specifically and in general with each other. (Wong, Agarwal et al. 2004) analyzed the developed and developing economies stock markets with context of long-run relationship. The sample of developed economies was consisting of UK, US, and Japan Hong-Kong Singapore while the developing were developing countries Thailand, Malaysia, Taiwan and Korea equity markets. The study demonstrated the weekly prices of stocks of 22 years which were starting from Jan 1981 to Dec 2002. In another study conducted by(Phylaktis and Ravazzolo 2005) to find the linkages among a group of Pacific Basin, the US and Japan over a period of 1980 to 1998. They found that the markets were not interlinked. Long run relationship among a country with its major trading partner has been explored by Chancharat and Valadkhani (2007).(Aktan and Masood 2010) studied explored the co-movement between stocks of Argentina, Brazil, China, India and Russia with the stock markets of US. (Arouri and Nguyen 2010) studied the inter-relatedness between markets of GCE countries as well as the developed world economies. The study covered the data which was ranged by June 2, 2005 to April 2, 2008.(Guidi, Gupta et al. 2011) examined the long-term co-movement relationship between the Central and Eastern Europe (CEE) equity markets and German equity markets. A few other factors suggested for stock market integration are inflation differential, bilateral trade relations, interest rate differential, and characteristics of stock markets like size and volatility. (Fifield, Power et al. 2011) on the basis of his study argued that South African stock markets show independency with world's major stock markets and on the other hand the South African market show dependency on foreign Stock markets economy. The long/short term relationship among the equity markets of India, Singapore and Malaysia, and the data was from daily stock prices started from July, 1997 to February, 2005. (Suchismita and Paramita 2006) studied the relation of India with two developed equity markets of the Japan and US and few developing economies. (Marimuthu and Kok 2010) researched the long/short term relationship among Malaysian stock market as well as Hong Kong, Taiwan and South Korea. 


\subsection{Pakistani Equity Market}

Hussain and Saidi (2000) researched the link of the KSE-100 index with global markets. The study took into the consideration weekly data from Jan, 1983 to Dec, 1993 and found poor level of integration. The inter-relatedness among the South Asian stock markets i.e., Pakistan, India, Sri Lanka and developed markets of US, Japan and UK was studied by Lamba (2005). To know the existence of long-term co-integration movement between Pakistani equity market KSE-100 index and of US, UK, Australia Germany, France, Canada, Italy and Japan a study was conducted. To study the effect of Islamic occasions and other events, (Ullah, Khan et al. 2013) studied the stock market and reported that there is effect on many financial and economic variables on a constant basis like the country's inflation rate, unemployment rate, interest rate and many more because of Islamic and other events/festivals.

The study of (Nishat and Mustafa 2010) checked the empirical relationship between risk, return and trading volume in the Karachi Stock Exchange (KSE) using the GARCH-M technique, and data for the time period December 1991 to December 2010. (Jadbabaie, Molavi et al. 2012) in their study reported mixed results regarding causal relationship between macroeconomic indicators and stock exchange prices for the case of Pakistan. Khan, (2012) studied the aspects of the market liberalization, integration the market with the world markets, trading and settlement mechanism, and corporate governance issues. (Jawaid, Arif et al. 2011) studied the relation among equity markets of the South Asian countries, i.e. Pakistan, Bangladesh, India, and Nepal. The causal and dynamic co-integration relationship among the Pakistani stock market and stock markets of (G8) Group of Eight countries. The stocks were of Canada, France, Germany, Italy, Japan, Russia, UK and USA.

\section{Research Methodology}

It is utmost important to identify the philosophical assumption behind the current study. The current study seeks to explain the link of the three stock markets. Thus for links it is most preferable to undertake a positivistic philosophical approach. The use of positivistic approach is to test the theories and to reach the generalizable laws (Bell and Bryman 2007). According to (Pugh, MAcPHERSON et al. 1983) positivistic philosophical approach is used for the data collection so that generalized propositions can be tested. The main assumption behind the use of quantitative techniques was to numerically analyze the numerical facts and figures so that it may allow the comparison of three stock exchange markets. The data has been collected from secondary source of the stock market from January 2001 to December 2013. For this purpose the study consist of the daily stock prices of KSE 10 index, Shanghai Stock Exchange, SSE (China) and Kuala Lumpur Stock Exchange, KLSE (Malaysia).

\section{Research Hypothesis}

H1: There is significant correlation among Karachi Stock Exchange, Malaysian and Chinese Stock Markets.

$\mathrm{H} 2$ : There is a long term relationship among the selected stock markets with KSE-100.

H3: There exists short term relationship among the selected markets with KSE-100

\section{Results and Discussion}

A Perfect positive correlation shows that if one security moves in either direction, the second security would moves in same way. It means there is direct relationship. Contrary to this, perfectly negative correlation exhibit that inverse relationship if one security moves in either direction the other security will move in the opposite direction which is perfectly (-) negatively correlated. If there is correlation 0 , the movements of these securities would have said to be no correlation; these are entirely random.

Table 1. Correlation of the Three Markets

\begin{tabular}{llll}
\hline & KSE & KLSE & SSE \\
\hline KSE & 1 & 0.913191 & 0.782573 \\
KLSE & 0.91319 & 1 & 0.693351 \\
SSE & 0.78257 & 0.69335 & 1 \\
\hline
\end{tabular}


After applying the correlation test, it is evident that KSE-100 index has strongest correlation with Malaysia which is 0.91.KSE-100 Index has also strong correlation SSE which is 0.78 . The results attained through correlation are known that there are significant correlations between "Karachi Stock Exchange (KSE-100 Index), Kuala Lumpur Stock Exchange, KLSE (Malaysia) and Shanghai Stock Exchange, SSE (China). The lower level of correlation always gives attraction for the foreign as well as institutional investor to get that stream for portfolio diversification which may be benefitted by investing in KSE-100 Index (Pakistan).

\subsection{Unit Root Test}

To execute Co-integration Test, the condition was perceived as that the data was stationary at same order, Unit Root Test can be used to inspect the stationary on the Level, 1st Differential of all the four variables as well as 2ndDifferential of interest rate only tested through the Augmented Dickey Fuller, 1981.

H1: Unit Root exists between the selected stock Markets.

The above hypothesis will be rejected for that 3 data series at 5\% (0.05) level of significance which leads us to proceed further and investigate the long-term relationship among all the series by using Johansen Co-integration Test.

Table 2. Uni Root Test of the Selected Asian Stock Market

\begin{tabular}{lll}
\hline Variable & $\begin{array}{l}\text { Test type } \\
(\mathbf{c}, \mathbf{t}, \mathbf{n})\end{array}$ & $\begin{array}{l}\text { ADF test } \\
\text { Statistics }\end{array}$ \\
\hline KSE & & $-2.990372^{* *}$ \\
MAL & & $-2.163896^{* *}$ \\
$\Delta$ SSE & $-46.83283^{* *}$ \\
\hline
\end{tabular}

Note:

- The 1st differential of variable is Indicated $\Delta$

- The 2nd differential of variable is Indicated $\Delta \Delta$

- $\quad$ Null hypothesis * Rejected at .0 .01 level of significance

- Null hypothesis ** Rejected at 0.05 level of significance

- Intercept, trend, and lags are represented by term $\mathrm{c}, \mathrm{t}$, and $\mathrm{n}$ respectively.

By applying Unit root test, the result obtained from the Table.2 shown that the series of KSE-100 Index and MAL Stock Index are stationary at their level and the series became stationary at 5\%probability level where as the data series of SSE.

Table 3a. Multivariate Co-integration Test (Trace statistics)

\begin{tabular}{lllccc}
\hline Equity markets & $\begin{array}{l}\text { Hypothesize } \\
\text { No. of CE(s) }\end{array}$ & Eigen-value & Trace Statistic & $\begin{array}{c}\text { 5 Percent } \\
\text { Critical Value }\end{array}$ & $\begin{array}{c}\text { 1 Percent } \\
\text { Critical Value }\end{array}$ \\
\hline KSE & None** & 0.013680 & 98.22851 & 68.52 & 76.07 \\
MAL & At most 1 & 0.009516 & 53.54471 & 47.21 & 54.46 \\
SSE & At most 3 & 0.001705 & 5.945723 & 15.41 & 20.04 \\
\hline
\end{tabular}

Trace test indicates 2 co-integrating equation(s) at the $5 \%$ level

Trace test indicates 1 co-integrating equation(s) at the $1 \%$ level

$*(* *)$ denotes rejection of the hypothesis at the $5 \%(1 \%)$ level

Table 3b. Multivariate Co-integration Test (Maximum Eigenvalue Statistics)

\begin{tabular}{llllcc}
\hline Equity markets & $\begin{array}{l}\text { Hypothesize } \\
\text { No. of CE(s) }\end{array}$ & Eigen-value & $\begin{array}{l}\text { MaxEigen } \\
\text { Statistic }\end{array}$ & $\begin{array}{c}\text { 5 Percent } \\
\text { Critical Value }\end{array}$ & $\begin{array}{c}\text { 1 Percent } \\
\text { Critical Value }\end{array}$ \\
\hline KSE & None** & 0.013680 & 44.68380 & 33.46 & 38.77 \\
MAL & At most 1 $*$ & 0.009516 & 31.01899 & 27.07 & 32.24 \\
SSE & At most 3 & 0.001705 & 5.535882 & 14.07 & 18.63 \\
Max-Eigen value test indicates 2 co-integrating equation(s) at the 5\% level & & \\
Max-Eigen value test indicates 1 co-integrating equation(s) at the 1\% level & & \\
*(**)denotes rejection of the hypothesis at the 5\%(1\%) level &
\end{tabular}


Table 3c. Bi-Variate Co-integration Test

\begin{tabular}{|c|c|c|c|c|c|}
\hline Variables & $\begin{array}{l}\text { Hypothesize } \\
\text { No. of CE(s) }\end{array}$ & Eigen-value & Trace Statistic & $\begin{array}{c}5 \text { Percent } \\
\text { Critical Value } \\
\end{array}$ & Remarks \\
\hline \multirow[t]{2}{*}{ Kse-MAL } & None* & 0.002845 & 17.39611 & 15.49471 & Existence of 2 \\
\hline & At most $1 *$ & 0.002507 & 7.147004 & 03.84146 & co-integrating \\
\hline \multirow[t]{2}{*}{ Kse-SSE } & None* & 0.007919 & 26.81852 & 15.49471 & Existence of 1 \\
\hline & At most $1 *$ & 0.000311 & 1.009771 & 03.84146 & co-integrating \\
\hline \multicolumn{6}{|c|}{ Trace test indicates 2 co-integrating equation(s) at the 0.05 level } \\
\hline \multicolumn{6}{|c|}{$*$ denotes rejection of the hypothesis at the 0.05 level } \\
\hline \multicolumn{6}{|c|}{ **MacKinnon-Haug-Michelis (1999)p-values } \\
\hline \multicolumn{6}{|c|}{ Max-eigenvalue test indicates no co-integrating at the 0.05 level } \\
\hline \multicolumn{6}{|c|}{$*$ denotes rejection of the hypothesis at the 0.05 level } \\
\hline \multicolumn{6}{|c|}{ **MacKinnon-Haug-Michelis (1999)p-values } \\
\hline
\end{tabular}

Decision criterion defines that, if $\mathrm{H} 0<0.05$ then reject the null hypothesis. By this test, it is viewed that there either uni-directional Granger Causality exits or bi-directional Granger Causality among KSE-100 Index and selected Asian Stock/Equity Markets.

The results indicate that KSE-100 has uni-directional relationship with the MAL as MAL does not Granger Cause KSE-100 as $\mathrm{H} 0>0.05$ as the $\mathrm{P}$ value is 0.71 and KSE- 100 Granger Cause MAL as $\mathrm{H} 0<0.05$ as the $\mathrm{P}$ value is 0.009 . While KSE-100 does not Granger Cause SSE asH0 $>0.05$.

\section{Conclusion}

This study is conducted in a limited span of time and to check the co-integration. The study focuses on integration among East Asian markets including Shanghai Stock Exchange, SSE (China), Kuala Lumpur Stock Exchange and KLSE (Malaysia) with reference to Karachi Stock Exchange, KSE-100 index (Pakistan). EAC (East Asian markets) have revealed rich integration except the equity market Pakistan. These results can be referring to the geographical and trade associations which are present between these countries. Pakistan and China have very strong relations but because of tough trade regulations of the trade volume is still low. Having glance on the results shown by correlation matrix, it might be carefully said, it is evident that KSE-100 index has strongest correlation with Malaysia. KSE-100 Index has also strong correlation with SSE. The lower level of correlation always offers attraction for the foreign as well as institutional investor to get the benefit by of portfolio diversification by investing in KSE-100 Pakistan. As same way, the increased correlation between stock markets reduces the opportunities for portfolio diversification. As it is evident that correlation analysis does not considering any cause and effect relationship it's merely discussed the strength as well as direction of the relationship. For better understand Co-integration analysis test which is performed to calculate the long term co-movement of stock price indices. There was shown by these results that Pakistani equity market behaves like exogenous because most of its shocks were because of its own innovation.

\section{References}

Aktan, B., \& O. Masood. (2010). The state of competition of the Turkish banking industry: An application of the Panzar-Rosse model. Journal of Business Economics and Management, 11(1), 131-145. http://dx.doi.org/10.3846/jbem.2010.07

Al-Fayoumi, N., \& Abuzayed B., et al. (2010). Ownership structure and earnings management in emerging markets: The case of Jordan. International Research Journal of Finance and Economics, 38(1), 28-47.

Arouri, M. E. H., \& D. K. Nguyen (2010). Oil prices, stock markets and portfolio investment: evidence from sector analysis in Europe over the last decade. Energy Policy, 38(8), 4528-4539. http://dx.doi.org/10.1016/j.enpol.2010.04.007

Azam, M., \& L. Lukman (2010). Determinants of foreign direct investment in India, Indonesia and Pakistan: A quantitative approach. Journal of Managerial Sciences, 4(1), 31-44. 
Bell, E., \& A. Bryman (2007). The ethics of management research: an exploratory content analysis. British Journal of Management, 18(1), 63-77. http://dx.doi.org/10.1111/j.1467-8551.2006.00487.x

Chen, M. A. (2005). Rethinking the informal economy: Linkages with the formal economy and the formal regulatory environment. Economic \& Social Affairs, DESA Working Paper No. 46.

Cheung, Y. L., \& Y. K. Ho (1991). The intertemporal stability of the relationships between the Asian emerging equity markets and the developed equity markets. Journal of Business Finance \& Accounting, 18(2), 235-253. http://dx.doi.org/10.1111/j.1468-5957.1991.tb00591.x

Chancharat, S., \& Valadkhani, A. (2007). An empirical analysis of the Thai and major international stock markets. Faculty of Commerce-Economics Working Papers, 178.

Divecha, A. B., \& J. Drach, et al. (1992). Emerging markets: a quantitative perspective. The Journal of Portfolio Management, 19(1), 41-50. http://dx.doi.org/10.3905/jpm.1992.409433

Eun, C., \& Shim, S. (1989). International transmission of stock market movements. Journal of Financial and Quantitative Analysis, 24, 241-256. http://dx.doi.org/10.2307/2330774

Fifield, S. G., \& D. M. Power, et al. (2011). Stock market integration in Africa. Managerial Finance, 37(3), 242-256. http://dx.doi.org/10.1108/03074351111113306

Guidi, F., \& R. Gupta, et al. (2011). Weak-form market efficiency and calendar anomalies for Eastern Europe equity markets. Journal of Emerging Market Finance, 10(3), 337-389. http://dx.doi.org/10.1177/097265271101000304

Gallo, G. M., \& Otranto, E. (2007). Volatility transmission across markets: a Multichain Markov Switching model. Applied Financial Economics, 17(8), 659-670. http://dx.doi.org/10.1080/09603100600722151

Husain, F., \& Saidi, R. (2000). The integration of Pakistani Equity Market with International Equity Markets: An Investigation. Journal of International Development, 12(2), 207-218. http://dx.doi.org/10.1002/(SICI)1099-1328(200003)12:2\%3C207::AID-JID636\%3E3.0.CO;2-Z

Jadbabaie, A., \& P. Molavi, et al. (2012). Non-Bayesian social learning. Games and Economic Behavior, 76(1), 210-225. http://dx.doi.org/10.1016/j.geb.2012.06.001

Jawaid, S. A. R. S. T., \& I. Arif, et al. (2011). Validity of capital asset pricing model in Pakistan: Evidence from Karachi Stock Exchange. African Journal of Business Management, 5(32), 12598.

Janakiramanan S., \& Lamba SA. (1998). An empirical examination of linkages between Pacific-Basin stock markets. $J$. Int. Financ. Mark., Inst. Money, 8, 155-17. http://dx.doi.org/10.1016/S1042-4431(98)00029-8

Jones, C. M. (2002). A century of stock market liquidity and trading costs. Available at SSRN 313681. http://dx.doi.org/10.2139/ssrn.313681

Jorion, P. (1985). International portfolio diversification with estimation risk. Journal of Business, 259-278. http://dx.doi.org/10.1086/296296

Kasa, K. (1992). Common stochastic trends in international stock markets. Journal of Monetary Economics, 29, 95-124.

Khan M. S. (2014). Macroeconomic variables and its impact on KSE-100 index.Universal. Journal of Accounting and Finance, 2(2), 33-39. http://dx.doi.org/10.13189/ujaf.2014.02020.

Marimuthu, M., \& N. K. Kok. (2010). Malaysian and Tiger Market Linkages: An Analysis on the Long Run Relationship and Risk Diversification. International Journal of Economics and Finance, 2(1), 159-170. http://dx.doi.org/10.5539/ijef.v2n1p159

Markowitz, H. (1952). Portfolio selection. The Journal of Finance, 7(1), 77-91. http://dx.doi.org/10.1111/j.1540-6261.1952.tb01525.x

Mustafa, K., \& Nishat, M. (2010). Risk, return and trading volume relationship in an emerging stock market: a case study of Karachi stock exchange. Savings and Development, 147-168.

Nishat, M., \& K. Mustafa (2010). Trading volume and serial correlation in stock returns in an emerging market: a case study of Pakistan. Philippine Review of Economics, 45(2).

Phylaktis, K., \& F. Ravazzolo (2005). Stock prices and exchange rate dynamics. Journal of International Money and Finance, 24(7), 1031-1053. http://dx.doi.org/10.1016/j.jimonfin.2005.08.001 
Pugh, C. W., \& G. G. MAcPHERSON, et al. (1983). Characterization of nonlymphoid cells derived from rat peripheral lymph. The Journal of experimental medicine, 157(6), 1758-1779. http://dx.doi.org/10.1084/jem.157.6.1758

Roca, E. (1999). Short-term and long-term price linkages between the equity markets of Australia and its major trading partners. Applied Financial Economics, 9, 501 -511. http://dx.doi.org/10.1080/096031099332168

Sheng HC, \& Tu AH (2000). A study of co-integration and variance decomposition among national equity indices before and during the period of the Asian financial crisis. J. Multinational Finan. Manage., 10, 345-365. http://dx.doi.org/10.1016/S1042-444X(00)00034-7

Suchismita, B., \& M. Paramita (2006). A study of Inter linkages between the Indian Stock Market and some other emerging and developed markets. 9th Capital Market Conference Paper, Indian Institute of Capital Markets India.

Subramanian, U. (2008). Cointegration of stock markets in East Asia. European Journal of Economics, Finance and Administrative Sciences, 14, 84-92.

Ullah, M., \& M. U. Khan, et al. (2013). An ethnobotanical survey of indigenous medicinal plants in Wana district south Waziristan agency, Pakistan. Journal of ethnopharmacology, 150(3), 918-924. http://dx.doi.org/10.1016/j.jep.2013.09.032

Wong, W.-K., \& A. Agarwal, et al. (2004). Financial integration for India stock market: A fractional co-integration approach. Finance India, 18(4), 1581.

World Bank (1997). Private Capital Flows to Developing Countries. Oxford University Press: New York. 